\title{
Review
}

Simranjot Kaur ${ }^{1}$ / Leonid N. Maslov ${ }^{2}$ / Nirmal Singh ${ }^{1} /$ Amteshwar Singh Jaggi ${ }^{3}$

\section{Dual role of T-type calcium channels in anxiety-related behavior}

\author{
${ }^{1}$ Department of Pharmaceutical Sciences and Drug Research, Punjabi University Patiala, Patiala 147002, India \\ ${ }^{2}$ Laboratory of Experimental Cardiology, Institute of Cardiology, Tomsk 634012, Russia \\ ${ }^{3}$ Department of Pharmaceutical Sciences and Drug Research, Punjabi University Patiala, Patiala 147002, India, Mobile: \\ +919501016036, E-mail: jaggiamteshwar@gmail.com
}

\begin{abstract}
:
T-type calcium channels are low voltage activated calcium channels that are widely expressed in various brain regions including stress-responsive regions. These channels regulate the diverse functions of the central nervous system, and modulation of these channels is shown to modulate the anxiety. Studies have described that modulation of T-type calcium channels may either aggravate or ameliorate anxiety-related behavior, suggesting the dual role of these channels. The studies employing animals with overexpression of T-type calcium channels reported their anxiety-inducing role. Therefore, the blockade of these channels using various pharmacological agents such as ethosuximide, plant extracts of linalool or rosemary, and corticotropin-releasing factor (CRF) is reported to ameliorate anxiety. On the contrary, knockout of the gene encoding these channels predisposes the rodents to anxiety-related disorders, suggesting the anxiety-attenuating role of these channels. It may be possible that these channels in normal or basal state attenuate anxiety, whereas activation of these channels in stressful condition may produce anxiety. The present review describes the dual role of T-type calcium channels in anxiety-related behavior in both preclinical and clinical studies.
\end{abstract}

Keywords: anxiety, behavior, cacna1h gene, ethosuximide, T-type calcium channels

DOI: $10.1515 / \mathrm{jbcpp}-2019-0067$

Received: February 27, 2019; Accepted: August 23, 2019

\section{Introduction}

Anxiety is a normal emotion that helps a person to be aware of forthcoming risk situations that may be real or imaginary. A persistent and increased level of anxiety is contemplated as a neuropsychiatric disorder that causes disturbances in the physical and mental health [1], [2]. According to the Diagnostic and Statistical Manual of Mental Disorders, Fifth Edition, anxiety disorders include disorders having features of excessive fear and related behavioral disturbances. These disorders include separation anxiety disorder, social anxiety disorder (social phobia), panic disorder, agoraphobia, generalized anxiety disorder and anxiety disorders due to other medical conditions and medication/substance. According to two major studies in the United States-the Epidemiological Catchment Area study and the National Comorbidity Survey study, the estimated lifetime prevalence rates for individual anxiety disorders are as follows: $2.3 \%-2.7 \%$ for panic disorder, $4.1 \%-6.6 \%$ for generalized anxiety disorder and $2.6 \%-13.3 \%$ for social phobia [3]. In the United States, the approximate prevalence of the anxiety disorders is $3.1 \%$ and $5.7 \%$ over a patient's lifetime. Moreover, the prevalence of anxiety disorder is twice in women in comparison with men [4].

Calcium channels are broadly classified in to two types, voltage-gated calcium channels and ligand-gated calcium channels. Voltage-gated calcium channels are more prominent, and these respond to changes in the voltage across the membrane by allowing the entry of $\mathrm{Ca}^{2+}$ ions inside the cell, which are one of the main signal transduction elements in the neurons. These voltage-gated channels are further subdivided into two types: high voltage activated channels, consisting of L-type calcium channels, P/Q-type calcium channels and N-type calcium channels; and low voltage activated (T-type) calcium channels [5], [6], [7]. Previous studies have demonstrated that even a small membrane depolarization of the cell membrane is responsible for the activation of low-voltage activated T-type calcium channels [8], [9].

T-type calcium channels are expressed throughout the brain, especially in stress-sensitive regions of the brain including the amygdala, hippocampus, prefrontal cortex, temporal lobe and dorsal region of dorsal raphe 
nucleus [6], [10], [11]. T-type $\mathrm{Ca}^{2+}$ channels have been associated with a wide range of physiological processes such as sleep [12], neuronal firing, pain [13], [14] and motor coordination [15]. Disturbance in these channels leads to various neurological and neuropsychiatric disorders such as depression, memory impairments [16], cognitive deficits [17] and epilepsy [18]. Therefore, modulation of T-type calcium channels may be involved in the aggravation or amelioration of anxious symptoms [5], [19]. T-type calcium channels play a dual role in anxiety. Some studies have shown that overexpression of $\mathrm{Ca}_{\mathrm{v}} 3.2 \mathrm{~T}$-type calcium channels produce anxiety-like behavior, and inhibition of activity of these channels shows anxiolytic activity [7], [20], [21]. Some studies have described that knockout of $\mathrm{Ca}_{\mathrm{v}} 3.2 \mathrm{~T}$-type $\mathrm{Ca}^{2+}$ channels cause the development of anxiety-related behaviors [5], [22]. The present review describes the dual role of T-type $\mathrm{Ca}^{2+}$ channels in the anxiety-related behavior in preclinical and clinical studies using various behavioral tests and biochemical parameters.

\section{Opening of T-Type $\mathrm{Ca}^{2+}$ channels induces anxiety-related behavior and T-type $\mathrm{Ca}^{2+}$ channel blockers attenuate anxiety}

There have been studies documentixng that the opening of T-type $\mathrm{Ca}^{2+}$ channels produces anxiety and the blockade of these channels attenuates anxiety-related behavior. The study of Alaoui et al. suggests that the beneficial effects of two Mediterranean plants, i.e. lavender and rosemary, in nervous disorders such as anxiety and mood are mediated through the blockade of T-type calcium channels. It was shown that linalool and rosamarinic acid, the major active components present in the extracts of lavender and rosemary, respectively, modify the electrophysiological properties of recombinant T-type calcium channel $\left(\mathrm{Ca}_{\mathrm{v}} 3.2\right)$ expressed in HEK$293 \mathrm{~T}$ cells. These active components inhibited T-type calcium channels in a concentration-dependent manner and elevated a negative shift of steady-state inactivation of the $\mathrm{Ca}_{\mathrm{v}} 3.2$ current, without showing any effect on activation properties [7]. The volatile compounds such as linalool and linalyl acetate that comprise lavender essential oil have demonstrated the therapeutic properties in disorders such as in anxiety in preclinical studies [23]. Furthermore, the anxiolytic activities of lavender have been attributed to linalool [24], and the latter is reported to attenuate stress-induced psychological parameters [25]. Moreover, lavender oil has been shown to reduce the calcium influx by modulating the voltage-dependent calcium channels [19]. Similarly, rosamarinic acid-containing plants such as Rosmarinus officinalis and Melissa officinalis also show an anxiolytic behavior [26]. Moreover, rosamarinic acid has also been reported to prevent anxiety-related behavior in cerebral-injured rats [27]. Accordingly, it has been proposed that the inhibition of T-type calcium channels could contribute to the anxiolytic effects of linalool- and rosamarinic acid-containing plants [7].

The report of Tao et al. suggests that the activation of corticotropin-releasing factor (CRF) receptor 1 by CRF peptides such as CRF or urocortin-1 selectively inhibits $\mathrm{Ca}_{\mathrm{v}} 3.2 \mathrm{~T}$-type calcium channels. The CRF peptides including CRF and urocortins 1-3 are regulators of mammalian stress and are implicated in disorders such as anxiety [28], [29]. Mechanistically, it has been reported that the activation of CRF receptor 1 by either CRF or urocortin 1 reversibly and selectively inhibits $\mathrm{Ca}_{\mathrm{v}} 3.2$ currents in HEK-293 T cells $\left(\mathrm{IC}_{50} \approx 30 \mathrm{nM}\right)$ without modulating $\mathrm{Ca}_{\mathrm{v}} 3.1$ or $\mathrm{Ca}_{\mathrm{v}} 3.3$ channels. Moreover, the selective blockade of CRF receptors 1 using astressin abolished CRF-mediated inhibition of $\mathrm{Ca}_{\mathrm{v}} 3.2$ channels in a significant manner. The CRF receptor 1-mediated inhibition of $\mathrm{Ca}_{\mathrm{v}} 3.2 \mathrm{~T}$-type calcium channel was dependent upon the activation of cholera toxin-sensitive Gprotein $\beta_{\gamma}$ subunits $\left(\mathrm{G}_{\beta \gamma}\right)$. Accordingly, it may be proposed that CRF peptides may produce antianxiety effects by activation of CRF receptor 1 , which in turn may inhibit $\mathrm{Ca}_{\mathrm{v}} 3.2$-type calcium channel using cholera toxinsensitive $\mathrm{G}_{\beta \gamma}$ signaling pathway [21]. Moreover, it has also been shown that the inhibitory effects of CRF-related peptide (urocortin 1) on T-type $\mathrm{Ca}^{2+}$ channels were abolished by specific CRF 1 receptor antagonist as well as by protein kinase C (PKC) inhibitors. Moreover, PKC activator (phorbol 12-myristate 13-acetate) mimicked the effects of urocortin and inhibited T-type calcium channels. It suggests that CRF/urocortin acts on CRF 1 receptors 1 to trigger PKC signaling pathway to inhibit T-type $\mathrm{Ca}^{2+}$ channels [30].

Ji et al. demonstrated the role of acute ethosuximide exposure in the modulation of the anxiety-related behavior in zebra fish larvae. The exposure of ethosuximide in low doses $(2,5$ and $10 \mathrm{mmol} / \mathrm{L})$ was reported to increase the locomotor response (distance travelled per minute). Moreover, it led to the amelioration of thigmotaxis behavior, suggesting its anxiolytic effects. On the contrary, high doses of ethosuximide (20 and 40 $\mathrm{mmol} / \mathrm{L}$ ) were reported to increase the thigmotaxis behavior and decrease the locomotor response, indicating that it results in the development of anxiety in high doses [31]. The study of Powell et al. demonstrated the difference in the pattern of anxiety-related behavior in two different strains of rats, i.e. genetic absence epilepsy rats (GAERS) and non-epileptic control (NEC) rats. It was shown that the GAERS displayed consistent anxiety and depressive-like behavior in comparison with the NEC rats. Mechanistically, a mutation was identified in the cacna1h gene, responsible for the expression of $\mathrm{Ca}_{\mathrm{v}} 3.2 \mathrm{~T}$-type calcium channel, in the GAERS strain. Indeed, in this strain, the mutation in cacna1h leads to the overexpression of $\mathrm{Ca}_{\mathrm{v}} 3.2 \mathrm{~T}$-type calcium channels, which 
is associated with the development of symptoms of anxiety. This gene was normally expressed in the NEC rats, and these rats did not develop anxiety; therefore, it may be suggested that the mutation of the gene in the GAERS strain leads to anxiety and depressive-like behavior [20].

The study of Dezsi et al. also reported that chronic treatment with ethosuximide ameliorates epileptogenesis and behavioral comorbidity such as anxious behavior in the GAERS strain, a model of genetic generalized epilepsy. Animals (GAERS and NEC rats) were administered with ethosuximide ( $200 \mathrm{mg} / \mathrm{kg}$, i.p.) in drinking water from the age of 3-24 weeks; after, that treatment was ceased, and all animals reverted to tap water, until the age of 34 weeks. The anxious behavior of the animals was assessed using an open field apparatus at the end of the 7th and 34th weeks. At the end of the seventh week, the distance travelled and the number of entries were significantly reduced in the open field apparatus in the GAERS as compared with the NEC rats, suggesting that the development of epilepsy/seizure leads to the induction of anxiety-related behavior. However, at the end of 34 weeks, the exploratory behavior was significantly restored in the ethosuximide-treated GAERS strain. It suggests that the upregulation of T-type calcium channels is responsible for the induction of anxiety and that its blockade may overcome anxiety-related behavior [32]. The study of Shaw et al. described the role of ethosuximide in the rat model of the absence epilepsy with anxiety as comorbidity, in Long-Evans rats. Anxietylike behavior was assessed using open field and elevated plus maze tests. Acute administration of ethosuximide (100 mg/kg, i.p.) led to significant improvement in the behavioral performances, and the rats displayed higher frequency of line crossing along with longer stay period in the center zone of the open field apparatus. It may be suggested that acute blockade of T-type $\mathrm{Ca}^{2+}$ channels may ameliorate anxiety-related behavior associated with seizures [33]. However, a study of Munro et al. described that ethosuximide (30 or $100 \mathrm{mg} / \mathrm{kg}$, i.p.) does not modulate the expression of anxiety-related behavior [34] (Table 1).

Table 1: Summarization of the dual role of T-type $\mathrm{Ca}^{2+}$ channels in anxiety-related behavior.

\begin{tabular}{|c|c|c|c|c|c|}
\hline S. no. & $\begin{array}{l}\text { Pharmacological } \\
\text { treatment }\end{array}$ & $\begin{array}{l}\text { Animals/cell } \\
\text { lines }\end{array}$ & $\begin{array}{l}\text { Function of T-type } \mathrm{Ca}^{2+} \\
\text { channels }\end{array}$ & Effect on anxiety & Reference \\
\hline \multicolumn{6}{|c|}{ Inhibition of T-type $\mathrm{Ca}^{2+}$ channels ameliorate anxiety-related behavior } \\
\hline 1 & $\begin{array}{l}\text { Lavender and } \\
\text { rosemary oil }\end{array}$ & $\begin{array}{l}\text { Cell line assay } \\
\text { (HEK293 cells) }\end{array}$ & $\begin{array}{l}\text { Inhibition of T-type } \mathrm{Ca}^{2+} \\
\text { channels }\end{array}$ & Decrease in anxiety & [7] \\
\hline 2 & Lavender oil & Mice & $\begin{array}{l}\text { Inhibition of T-type } \mathrm{Ca}^{2+} \\
\text { channels }\end{array}$ & $\begin{array}{l}\text { Decrease in } \\
\text { anxiety-related } \\
\text { behavioral alterations }\end{array}$ & [19] \\
\hline 3 & $\begin{array}{l}\text { Corticotropin- } \\
\text { releasing factor } \\
\text { peptides }\end{array}$ & $\begin{array}{l}\text { Cell line assay } \\
\text { (HEK293 cells) }\end{array}$ & $\begin{array}{l}\text { Inhibition of } \mathrm{Ca}_{\mathrm{v}} 3.2 \\
\text { T-type } \mathrm{Ca}^{2+} \text { channels }\end{array}$ & Decrease in anxiety & [21] \\
\hline 4 & $\begin{array}{l}\text { Ethosuximide }(2, \\
5 \text { and } 10 \\
\mathrm{mmol} / \mathrm{L})\end{array}$ & Zebra Fish & $\begin{array}{l}\text { Blockade of T-type } \mathrm{Ca}^{2+} \\
\text { channels }\end{array}$ & $\begin{array}{l}\text { Decrease in } \\
\text { anxiety-related } \\
\text { behavioral changes }\end{array}$ & [31] \\
\hline 5 & NA & $\begin{array}{l}\text { Genetic absence } \\
\text { epileptic rats } \\
\text { (GAERS) }\end{array}$ & $\begin{array}{l}\text { Overexpression of } \\
\mathrm{Ca}_{\mathrm{v}} 3.2 \mathrm{~T} \text {-type } \mathrm{Ca}^{2+} \\
\text { channels }\end{array}$ & $\begin{array}{l}\text { Consistent anxiety and } \\
\text { depressive-like behavior }\end{array}$ & [20] \\
\hline 6 & $\begin{array}{l}\text { Ethosuximide } \\
(200 \mathrm{mg} / \mathrm{kg})\end{array}$ & $\begin{array}{l}\text { Genetic absence } \\
\text { epileptic rats } \\
\text { (GAERS) }\end{array}$ & $\begin{array}{l}\text { Blockade of T-type } \mathrm{Ca}^{2+} \\
\text { channels }\end{array}$ & $\begin{array}{l}\text { Decrease in } \\
\text { epilepsy-comorbid } \\
\text { anxiety-like behavior }\end{array}$ & [32] \\
\hline \multicolumn{6}{|c|}{ Genetic ablation of T-type $\mathrm{Ca}^{2+}$ channel aggravate anxiety-related behavior } \\
\hline 7 & NA & Mice & $\begin{array}{l}\text { Genetic ablation of } \\
\text { cacna1h gene }\left(\mathrm{Ca}_{\mathrm{v}} 3.2\right. \\
\left.\text { T-type } \mathrm{Ca}^{2+} \text { channels }\right)\end{array}$ & $\begin{array}{l}\text { Development of } \\
\text { anxiety-related behavior }\end{array}$ & [5] \\
\hline 8 & NA & Mice & $\begin{array}{l}\text { Ablation of } \mathrm{Ca}_{\mathrm{v}} 3.2 \\
\text { T-type } \mathrm{Ca}^{2+} \text { channels }\end{array}$ & $\begin{array}{l}\text { Development of anxiety, } \\
\text { sleep and memory } \\
\text { disorders }\end{array}$ & [22] \\
\hline
\end{tabular}

\section{Knockout of T-type $\mathrm{Ca}^{2+}$ Channels induces anxiety-related behavior}

In contrast to the above-described studies, there have been studies reporting that the blockade or knockout of T-type $\mathrm{Ca}^{2+}$ channels induces anxiety. Gangarossa et al. described the role of T-type $\mathrm{Ca}^{2+}$ channels in the development of anxious behavior, memory formation and response to psychostimulants using $\mathrm{Ca}_{\mathrm{v}} 3.2$-deficient mice. The mice with genetic ablation of cacna1h gene, responsible for encoding $\mathrm{Ca}_{\mathrm{v}} 3.2$ channels, showed an increase 
in anxiety-related behavior in comparison with wild type mice assessed in different tests including light/dark conflict, open field, marble burying and elevated plus maze tests. These mice also exhibited disruption of hippocampus-dependent memory functions as assessed on Y-maze, novel object recognition and spatial object recognition tests. Moreover, such mice also exhibited decreased sensitivity to psychostimulants including cocaine hydrochloride ( $15 \mathrm{mg} / \mathrm{kg}$, i.p.) and D-amphetamine sulfate $(2 \mathrm{mg} / \mathrm{kg}$, i.p.), which selectively increased the locomotor activity in wild-type mice, but not in $\mathrm{Ca}_{\mathrm{v}} 3.2$-deficient mice. Furthermore, administration of selective T-type calcium blocker TTA-A2 (1 mg/kg, p.o.) attenuated the cocaine- and amphetamine-induced hyperlocomotion in wild-type mice, suggesting that the actions of psychostimulants are mediated through the activation of the T-type calcium channels. Accordingly, it has been proposed that knockout of T-type calcium channels may lead to the development of anxiety-like behavior, memory disruption and induction of drug-induced behavioral alterations [5]. Another study has reported that ablation of genes responsible for expression of $\mathrm{Ca}_{\mathrm{v}} 3.2$ or disruption of T-type channels within the CNS, particularly in the hippocampus, contributes to the development of anxiety, sleep and memory disorders in mice. The importance of $\mathrm{Ca}_{\mathrm{v}} 3.2 \mathrm{~T}$-type voltage-gated channels specifically in the hippocampus was assessed using microarray transcriptome data of murine hippocampal RNA probes [22].

The study of Gironell and Lahoz described the role of ethosuximide in the development of anxious disorders during the exploration of this drug in subjects with essential tremor in an open label trial. The authors planned to conduct the clinical trial with 15 patients using a dose of $500 \mathrm{mg}$ of ethosuximide daily (b.i.d.), but the trial was stopped after seven patients' participation because of lack of efficacy. Moreover, ethosuximide led to high incidences of adverse effects such as anxiety, nervousness and dizziness, causing the patients (in $80 \%$ of patients) to stop the trial [35]. It suggests that the blockade of T-type calcium channels induces the development of anxiety (Table 1).

\section{Discussion}

Anxiety disorders are one of the most common types of psychiatric disorders, and the modulation of T-type calcium channels is reported to modulate anxiety-related behavior in preclinical studies as well as in clinical studies [19], [32], [35]. Studies have shown that the blockade of T-type $\mathrm{Ca}^{2+}$ channels by the use of either pharmacological agents such as ethosuximide [33], endogenous peptide CRF [21] or plant extracts such as linalool or rosemary ameliorates anxiety and related behaviors [7], [19]. The overexpression of T-type calcium channels in the GAERS strain has been correlated with the development of anxiety [20]. Moreover, the blockade of T-type calcium channels with ethosuximide is shown to ameliorate anxiety, as an important comorbidity in epilepsy [32]. However, studies based on the knockout of the gene responsible for the expression of T-type calcium channels have shown that the studied rodents are more prone to anxiety-related behavior [5].

Accordingly, it is proposed that T-type calcium channels may have a dual role in anxiety. The blockade of T-type calcium channels with a pharmacological agent may possibly attenuate anxiety; however, knock-out of these channels may predispose to anxiety-related disorder. The precise mechanisms describing the duality of T-type calcium channels in anxiety are not explored yet. It may be hypothesized that normally functional T-type $\mathrm{Ca}^{2+}$ channel, i.e. at the basal state, may inhibit the development of anxiety. This convention is based on the T-type calcium channel knockout studies [5]. Conversely, under a given stressful stimulus, these T-type calcium channels may be upregulated, and thus, overactivation of these channels may lead to the development of anxiety-related behavior. The studies showing amelioration of anxiety in the presence of T-type calcium channel blockers in different models of anxiety support the above convention [7], [19]. The dual role of T-type calcium channels is also reported in the study of Ji et al., describing that ethosuximide ameliorates anxiety in low doses, while it produces anxiety at high doses in the larvae of zebra fish [31]. It again suggests that inhibition of T-type calcium channels to a certain level may attenuate anxiety. However, the complete blockade of these channels or knockout of these channels may produce anxiety.

The molecular mechanisms involved in T-type calcium channel-mediated modulation of anxiety-like behavior are not explored yet. It has been observed that the modulation of T-type $\mathrm{Ca}^{2+}$ channels leads to the alterations in the level of various neurotransmitters including dopamine, serotonin and glutamate [36], [37], [38], [39]. The modulation of these neurotransmitters, i.e. decrease in the levels of dopamine and serotonin along with an increase in the level of glutamate, is associated with the development of anxiety-related disorders [40], [41], [42], [43]. Therefore, it may be proposed that the T-type $\mathrm{Ca}^{2+}$ channel may play an important role in modulating anxiety-related disorders by alterations in the levels of dopamine, serotonin and glutamate via unexplored signaling pathways. Moreover, some studies have shown the possible involvement of protein kinase $C$ pathway in inhibiting T-type calcium channels [30]; however, their precise association in anxiety-related behavior is unex- 
plored. Accordingly, future studies shall be designed to fully elucidate the dual role of T-type calcium channels along with the molecular mechanisms/signaling pathways contributing in modulating anxiety behavior.

\section{Conclusions}

T-type calcium channels may serve as an important target in anxiety-related disorder. These channels may inhibit anxiety in normal or basal state. However, the overactivation of channels during a stressful condition may produce anxiety, and hence, blockade of these channels during a stressful state may possibly ameliorate anxiety.

\section{Acknowledgments}

The authors are grateful to Department of Pharmaceutical Sciences and Drug Research, Punjabi University, Patiala, India for supporting this study.

Author contributions: All the authors have accepted responsibility for the entire content of this submitted manuscript and approved submission.

Research funding: None declared.

Competing interests: Authors state no conflict of interest.

\section{References}

[1] Crocq MA. A history of anxiety: from Hippocrates to DSM. Dialogues Clin Neurosci 2015;17:319-25.

[2] Bartlett AA, Singh R, Hunter RG. Anxiety and epigenetics. Adv Exp Med Biol 2017;978:145-66.

[3] Moustafa AT, Moazzami M, Engel L, Bangert E, Hassanein M, Marzouk S, et al. Prevalence and metric of depression and anxiety in systemic lupus erythematosus: a systematic review and meta-analysis. Semin Arthritis Rheum 2019;49:30563-8.

[4] Stein MB, Sareen ]. Clinical practice: generalized anxiety disorder. N Engl ] Med 2015;373:2059-68.

[5] Cangarossa G, Laffray S, Bourinet E, Valjent E. T-type calcium channel $\mathrm{Ca}_{\mathrm{v}} 3.2$ deficient mice show elevated anxiety, impaired memory and reduced sensitivity to psychostimulants. Front Behav Neurosci 2014;8:92.

[6] Bali A, Gupta S, Singh N, Jaggi AS. Implicating the role of plasma membrane localized calcium channels and exchangers in stress-induced deleterious effects. Eur ] Pharmacol 2013;714:229-38.

[7] Alaoui C, Chemin ], Fechtali T, Lory P. Modulation of T-type Ca2 ${ }^{+}$channels by lavender and rosemary extracts. PLoS One 2017;12:e0186864.

[8] Perez-Reyes E. Molecular physiology of low-voltage-activated t-type calcium channels. Physiol Rev 2003;83:117-61.

[9] Llinás RR, Choi S, Urbano F], Shin HS. Gamma-band deficiency and abnormal thalamocortical activity in P/Q-type channel mutant mice. Proc Natl Acad Sci USA 2007;104:17819-24.

[10] Knutson KM, Rakowsky ST, Solomon ], Krueger F, Raymont V, Tierney MC, et al. Injured brain regions associated with anxiety in Vietnam veterans. Neuropsychologia 2013;51:686-94.

[11] Chen X, Hackett PD, DeMarco AC, Feng C, Stair S, Haroon E, et al. Effects of oxytocin and vasopressin on the neural response to unreciprocated cooperation within brain regions involved in stress and anxiety in men and women. Brain Imaging Behav 2016;10:581-93.

[12] Anderson MP, Mochizuki T, Xie ], Fischler W, Manger JP, Talley EM, et al. Thalamic Ca $\mathrm{V}_{v} 3.1 \mathrm{~T}_{\text {-type }} \mathrm{Ca}^{2+}$ channel plays a crucial role in stabilizing sleep. Proc Natl Acad Sci USA 2005;102:1743-8.

[13] Todorovic SM, Jevtovic-Todorovic V. T-type voltage-gated calcium channels as targets for the development of novel pain therapies. Br ] Pharmacol 2011;163:484-95.

[14] Francois A, Kerckhove N, Meleine M, Alloui A, Barrere C, Celot A, et al. State-dependent properties of a new T-type calcium channel blocker enhance $\mathrm{Ca}(\mathrm{V}) 3.2$ selectivity and support analgesic effects. Pain 2013;154:283-93.

[15] Park YG, Park HY, Lee C], Choi S, Jo S, Choi H, et al. Ca(V)3.1 is a tremor rhythm pacemaker in the inferior olive. Proc Natl Acad Sci USA 2010;107:10731-6.

[16] Yabuki Y, Jing X, Fukunaga K. The T-type calcium channel enhancer SAK3 inhibits neuronal death following transient brain ischemia via nicotinic acetylcholine receptor stimulation. Neurochem Int 2017;108:272-81.

[17] Husain N, Yabuki Y, Shinoda Y, Fukunaga K. Acute treatment with T-type calcium channel enhancer SAK3 reduces cognitive impairments caused by methimazole-induced hypothyroidism via activation of cholinergic signaling. Pharmacology 2018;10:309-21.

[18] Cain SM, Snutch TP. T-type calcium channels in burst-firing, network synchrony, and epilepsy. Biochim Biophys Acta 2013;1828:1572-8.

[19] Schuwald AM, Nöldner M, Wilmes T, Klugbauer N, Leuner K, Müller WE. Lavender oil-potent anxiolytic properties via modulating voltage dependent calcium channels. PLoS One 2013;8:e59998. 
[20] Powell KL, Tang H, Ng C, Guillemain I, Dieuset G, Dezsi G, et al. Seizure expression, behavior, and brain morphology differences in colonies of genetic absence epilepsy rats from Strasbourg. Epilepsia 2014;55:1959-68.

[21] Tao ], Hildebrand ME, Liao P, Liang MC, Tan C, Li S, et al. Activation of corticotropin-releasing factor receptor 1 selectively inhibits Ca 3.2 T-type calcium channels. Mol Pharmacol 2008;73:1596-609.

[22] Papazoglou A, Henseler C, Lundt A, Wormuth C, Soos ], Broich K, et al. Cender specific hippocampal whole genome transcriptome data from mice lacking the $\mathrm{Ca}_{\mathrm{v}} 2.3 \mathrm{R}$-type or $\mathrm{Ca}_{\mathrm{v}} 3.2 \mathrm{~T}$-type voltage-gated calcium channel. Data Brief 2017;12:81-6.

[23] Woronuk G, Demissie Z, Rheault M, Mahmoud S. Biosynthesis and therapeutic properties of Lavandula essential oil constituents. Planta Med 2011;77:7-15.

[24] Sugawara Y, Hara C, Tamura K, Fujii T, Nakamura K, Masujima M, et al. Sedative effect on humans of inhalation of essential oil of linalool: sensory evaluation and physiological measurements using optically active linalool. Anal Chim Acta 1998;365:293-9.

[25] Hoferl M, Krist S, Buchbauer G. Chirality influences the effects of linalool on physiological parameters of stress. Planta Med 2006;72:1188-92.

[26] Pereira P, Tysca D, Oliveira P, da Silva Brum LF, Picada JN, Ardenghi P. Neurobehavioral and genotoxic aspects of rosamarinic acid. Pharmacol Res 2005;52:199-203.

[27] Zhang M, Yan H, Li S, Yang ]. Rosamarinic acid protects rat hippocampal neurons from cerebral ischemia/reperfusion injury via the Akt/JNK3/caspase-3 signaling pathway. Brain Res 2017;1657:9-15.

[28] Reul JM, Holsboer F. Corticotropin-releasing factor receptors 1 and 2 in anxiety and depression. Curr Opin Pharmacol 2002;2:23-33.

[29] Bale TL, Vale WW. CRF and CRF receptors: role in stress responsivity and other behaviors. Ann Rev Pharmacol Toxicol 2004;44:525-7.

[30] Kim Y, Park MK, Uhm DY, Chung S. Modulation of T-type $\mathrm{Ca}^{2+}$ channels by corticotropin-releasing factor through protein kinase $\mathrm{C}$ pathway in MN9D dopaminergic cells. Biochem Biophys Res Commun 2007:358:796-801.

[31] ]i Y, Lin ], Peng X, Liu X, Li F, Zhang Y, et al. Behavioural responses of zebrafish larvae to acute ethosuximide exposure. Behav Pharmacol 2017;28:428-40.

[32] Dezsi G, Ozturk E, Stanic D, Powell KL, Blumenfeld H, O'Brien T], et al. Ethosuximide reduces epileptogenesis and behavioral comorbidity in the CAERS model of genetic generalized epilepsy. Epilepsia 2013;54:635-43.

[33] Shaw FZ, Chuang SH, Shieh KR, Wang Y]. Depression- and anxiety-like behaviors of a rat model with absence epileptic discharges. Neuroscience 2009;160:382-93.

[34] Munro G, Erichsen HK, Mirza NR. Pharmacological comparison of anticonvulsant drugs in animal models of persistent pain and anxiety. Neuropharmacology 2007;53:609-18.

[35] Gironell A, Marin-Lahoz ]. Ethosuximide for essential tremor: an open-label trial. Tremor Other Hyperkinet Mov (NY) 2016;6:378.

[36] Cui G, Okamoto T, Morikawa H. Spontaneous opening of T-type $\mathrm{Ca}^{2+}$ channels contributes to the irregular firing of dopamine neurons in neonatal rats. J Neurosci 2004;24:11079-87.

[37] Wang S, Yabuki Y, Matsuo K, Xu ], Izumi H, Sakimura K, et al. T-type calcium channel enhancer SAK3 promotes dopamine and serotonin releases in the hippocampus in naive and amyloid precursor protein knock-in mice. PLoS One 2019;14:e0211590.

[38] Louiset E, Duparc C, Lenglet S, Comez-Sanchez CE, Lefebvre H. Role of cAMP/PKA pathway and T-type calcium channels in the mechanism of action of serotonin in human adrenocortical cells. Mol Cell Endocrinol 2017;441:99-107.

[39] Liu DD, Lu JM, Zhao QR, Hu C, Mei YA. Growth differentiation factor-15 promotes glutamate release in medial prefrontal cortex of mice through upregulation of T-type calcium channels. Sci Rep 2016;6:28653.

[40] Kotlinska ]H, Lopatynska-Mazurek M, Gawel K, Gabka P, Jenda-Wojtanowska M, Kruk-Slomka M, et al. Impact of the metabotropic glutamate receptor 7 (mClu7) allosteric agonist, AMNo82, on fear learning and memory and anxiety-like behavior. Eur ] Pharmacol 2019;858:172512.

[41] Onaolapo O], Aremu OS, Onaolapo AY. Monosodium glutamate-associated alterations in open field, anxiety-related and conditioned place preference behaviours in mice. Naunyn Schmiedebergs Arch Pharmacol 2017;390:677-89.

[42] Azevedo H, Ferreira M, Costa RW, Russo V, Russo E, Mascarello A, et al. Preclinical characterization of ACH-000029, a novel anxiolytic compound acting on serotonergic and alpha-adrenergic receptors. Prog Neuropsychopharmacol Biol Psychiatry 2019;95:109707.

[43] Zhang M, Liu Y, Zhao M, Tang W, Wang X, Dong Z, et al. Depression and anxiety behaviour in a rat model of chronic migraine. ] Headache Pain 2017;18:27. 